\title{
Professor H. V. J. Fernando - A tribute
}

\author{
Ravindra Fernando
}

Department of Forensic Medicine and Toxicology, Faculty of Medicine, Colombo

MLSL. Vol 2. No 1. March. pp 26-28

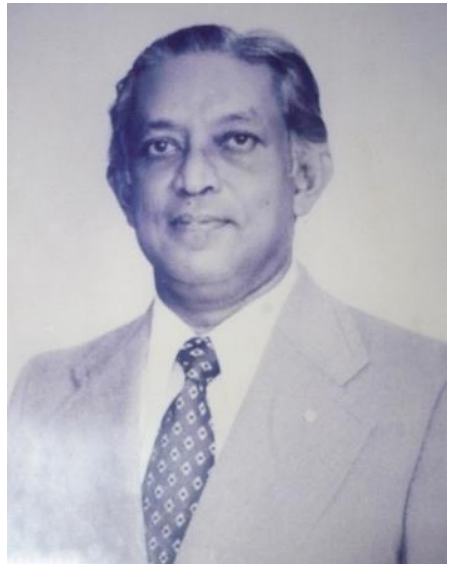

On $1^{\text {st }}$ April 1919 a child was born to wealthy parents, Henry Domingo Fernando and Vivienne Muriel Fernando (nee de Mel), who was destined to become an intelligent doctor, a great academic, a teacher par excellence, a true friend, a faithful colleague and a great humanist. He was named Hubert Vernon Jerrold.

He was a brilliant student at Royal College, Colombo and entered the University College, Colombo, in 1937 and the Medical College of the University of Ceylon in 1938. In 1943, he passed MBBS (Ceylon) with Second Class Honours. From 1943 to 1947 he worked as a medical officer in the Department of Health Services serving as a House Officer to the Professor of Medicine and in the Department of Pathology. He then worked at the Medical Research Institute, Colombo and as a pathologist in the Civil Hospital, Kandy. He resigned from this post in July 1947 to proceed to the United Kingdom to pursue higher studies. Dr. Fernando could not enter the MD programme in the UK without a primary British medical degree. Therefore, to obtain MBBS of the University of London, he was attached for two years to the School of Medicine, University of Leeds, as an External Student. During this period he also worked part time with Professor Matthew Stewart, Professor of Pathology of the University.

He passed M.B.B.S. (London) with ease in 1949 and was appointed as Demonstrator in the Department of Pathology of the King's College Hospital Medical School, London. He took part in the routine work of the Department and the teaching. In June 1952, he obtained MD (London) in Pathology with Morbid Anatomy as his special subject.

After his MD, he worked with Dr. Keith Simpson, then a Home Office Pathologist and a Reader in Forensic Medicine, at Guy's Hospital Medical School, University of London. He also spent some time in the Biological Laboratories of Scotland Yard learning their crime investigating techniques.

After returning to Ceylon in October 1952, he joined as a Pathologist of the Colombo Group of Hospitals.

On $13^{\text {th }}$ February 1953 after Dr. Fernando's selection to the University of Colombo, Professor G.S.W. de Saram, the first Professor of Forensic Medicine, wrote to the University stating that "Dr. Fernando be appointed on the maximum salary of a Grade 2 Lecturer and be stepped up to Grade 1 a year later, because he has obtained the highest degree in his specialty and has also acquired practical knowledge of medico-legal work under Dr. Keith Simpson who is one of the leading consultants to Scotland Yard. Dr. Simpson's high opinion of Dr. Fernando has already been submitted to the Selection Committee". On $4^{\text {th }}$ March 1953 Sir 
Ivor Jennings, the Vice- Chancellor appointed him to the lecturer post in the Department.

After the retirement of Professor de Saram in May 1958, he had been the acting Head of the Department of Forensic Medicine, and he was responsible for the administrative work of the Department.

Dr. H. V. J. Fernando was appointed the second Professor of Forensic Medicine on $10^{\text {th }}$ July 1959.

In 1961, Professor Fernando took one year sabbatical leave and proceeded to London and was successful in the Barrister's examination of the Lincoln's Inn of the Inns Court, London. However, he was not called to the bar due to inability to "keep dining terms" - a traditional requirement before a student is called to the bar at the Inns of Court.

During his sabbatical leave, he visited medicolegal institutions at London, Sheffield, Leeds, Edinburgh, Glasgow, Cambridge, Cardiff, and Copenhagen.

In January 1962, the Asia Foundation awarded a grant to Professor H. V. J. Fernando to visit the medico-legal institutions at New York, Connecticut, Washington, Chicago, Los Angeles and San Francisco in the USA.

Later he visited the All India Institute of Medical Sciences to attend a WHO conference on "Evaluation Methods in Medical Teaching". He has also visited Turkey and the Federal Republic of Germany to attend conferences. Participating in professional activities with dedication, Professor Fernando served as the President of the Medico-Legal Society of Sri Lanka in late seventies. He was the President of the Sri Lanka Cancer Society and served the Society with dedication.

His professional colleagues included Drs. W.D.L. Fernando, Chandra Amarasekera, Dr. Haris Ranasinghe, Dr. C. H. S. Jayawardene, Dr. N. Saravanapavananthan and Dr. S. Sivaloganathan. Professor Fernando always wrote very favourable reference letters to his juniors and also kept in touch with them when they went on study leave.

He had many friends in the international forensic scene. Some of them were Professor
Donald Teare, Professor of Forensic Medicine at St. George's Hospital, London, Dr. H. P. Terfloth, Institute of Forensic Medicine, University of Munchen, West Germany, Dr. J. M. Cameron, the Professor of Forensic Medicine at the London Hospital, Dr. Tom Noguchi, Chief Medical Examiner and Coroner for the County of Los Angeles, who was known as the "coroner to the stars", as he determined the causes of death in many high profile cases such as Marilyn Monroe, Robert F. Kennedy, Sharon Tate and Natalie Wood, Dr. W. G. Eckert and Dr Milton Helpern of the USA.

A keen and dedicated teacher in the Faculty of Medicine, Colombo, he held the post of Chairman of the Centenary Celebration Association of the Faculty in 1970 . He was the Founder Chairman of the Statistical Unit of the University of Ceylon.

In 1982, he became the Registrar of the Ceylon Medical Council when Professor Milroy Paul retired, and served in this position till 1994. During this period he compiled "An Index of Important Decisions of the Medical Council from 1948 to March 1996", and "Legislation relating to the Sri Lanka Medical Council formerly Ceylon Medical Council", which included a "Summary of Legislative Enactments from 1905".

He was the first Chairman of the Board of Study in Forensic Medicine in the Post Graduate Institute of Medicine, which commenced the postgraduate training in Forensic Medicine in Sri Lanka. He was responsible for the initial spade work of the Board to prepare the training programme and conducting the first couple of post graduate examinations.

Professor Fernando was consulted by the Attorney General's Department and the private bar for expert opinion in difficult cases and many eminent legal professionals visited him at his residence for expert opinion.

He performed the post mortem examinations of Mrs. Padmini Kularatna of Galle, who died of arsenic poisoning. In the well known Getangama murder case in Ratnapura, where a man murdered and hanged his wife with the help of his mistresses, Professor Fernando was 
requested by the Attorney-General's Department to advice on the post mortem findings of Dr. D.J. Bandara and Dr. Saravanapavananthan, who did the first and the second postmortems respectively.

In 1960s excavations at the site of Dakkina Thupa, Anuradhapura, were recommenced by Professor Senarath Paranavithana and when the ashes were recovered from the basement of Dakkina Thupa, which was believed to be of king Dutugemunu, they were sent to Professors $\mathrm{H}$ V J Fernando for expert opinion by the archaeologists.

When he was in King's College he contributed an article on "Pulmonary Aspergillosis Following Post-influenzal Bronchopneumonia Treated with Antibiotics" with J. D. Abbott, K. Gurling, and B. W. Meade to the prestigious British Medical Journal in 1952. Only very few Sri Lankans are fortunate enough to get an article published in the prestigious British Medical Journal.

Professor Fernando's other publications include "Forensic aspects of post-maturity" in the Ceylon Medical Journal in 1957, "Distribution of $\mathrm{A}-\mathrm{B}-\mathrm{O}$ and $\mathrm{M}-\mathrm{N}$ blood groups among the Ceylonese, their Significance in Forensic Work" in the Ceylon Journal of Medical Sciences in 1958, and "Survival after penetrating injury of the heart" with Dr. C. Mylvaganam, in the Journal of Forensic Medicine in 1959.

He presented several scientific papers with other colleagues. For example with Chandra Amarasekera, N. Saravanapavananthan and others he read papers on "Socio-medical aspects of road traffic accidents in Colombo" and "An epidemiological study of intentional violence in Colombo" at the Annual Scientific Sessions of the Sri Lanka Medical Association in 1979.
A very useful publication of Professor Fernando was "Injuries and their legal definition" with Consultant Surgeon Dr. A. Thavendran, Chief Justice H.N.G. Fernando, and eminent lawyer Eardley Perera in the Journal of the Colombo General Hospital in 1973.

Another joint publication with Chief Justice H.N.G. Fernando, Dr. Chandra Amarasekera and Dr. N. Saravanapavananthan and others was on "Hurt in relation to the Ceylon Penal Code" in the Sri Lanka Police Journal in 1974.

In 1984 Professor Fernando and I submitted a paper on "Examination and reporting of victims of assault to Police and Courts in Sri Lanka" for the Tenth Meeting of the International Association of Forensic Sciences, held in Oxford, England. The abstract of this article was published in the Journal of Forensic Science Society.

In September 1984, Professor Stanley Wijesundera, the then Vice Chancellor of the University wrote to Professor Fernando about his impending retirement stating that he would like to make special mention of the invaluable counsel and support given to him during his tenure of office as Vice Chancellor.

I wish to quote a sentence from Professor Fernando's reply. "I have always felt that loyalty is an important part of any service and I have tried to live up to it". A profound statement to be made note of! In 1944 young Dr. Fernando married Marie Constance Gwendoline Philip, a daughter of Dr. B.D.H. Philip from Kaluthara. Their son Nirmal and daughter Marina became accountants but one of his grand daughters, Sahani, is now a Consultant Anaesthetist in the USA. He retired on $31^{\text {st }}$ December 1984 and the Senate of the University elected him Emeritus Professor on $12^{\text {th }}$ September 1985. After a fruitful academic and social life Professor Fernando passed away peacefully on $2^{\text {nd }}$ May 1998. 